\title{
A personagem Nina, de Lúcio Cardoso, no contexto de sua tradução para o cinema
}

\author{
Aila Maria Leite Sampaio ${ }^{1}$
}

http://lattes.cnpq.br/5949186859109103

Enviado em: 19/08/2018

Aceito em: 09/12/2018

Resumo: O objetivo deste artigo é analisar a tradução da personagem Nina, do romance Crônica da casa assassinada (1959), de Lúcio Cardoso, para o filme Casa assassinada (1971), de Paulo César Saraceni. Utilizaremos como base teórica a concepção de adaptação fílmica como um tipo de reescritura, de André Lefevere (2007); leva-se em conta, pois, que o texto adaptado não é uma cópia do original, mas um novo texto. Assim, entendemos o processo como um dialogismo intertextual, considerando que todas as formas de texto são intersecções de outros textos (HUTCHEON, 2011). Os resultados da análise mostram que a maldade que se atribui a Nina, no romance, não pode ser vista como essencial, mas decorre da interpretação de seus atos pelo olhar dos outros; com o apagamento dessas vozes narrativas (FRIEDMAN, 2002), na obra fílmica, a personagem ganha mais espaço de subjetivação e o discurso sobre o mal atribuído a ela é suavizado, imprimindo na adaptação marcas da poética do diretor.

Palavras-chave: Mulher. Adaptação. Mal. Literatura Comparada. Narrativa fílmica.

Abstract: The objective of this article is to analyze the translation of the character Nina, from the novel Crônica da casa assassinada (1959), by Lúcio Cardoso, for the cinema, in the film Casa assassinada (1971), by Paulo César Saraceni. We will use as theoretical basis the conception of film adaptation as a type of rewriting, by André Lefevere (2007); it is therefore taken into account that the adapted text is not a copy of the original but a new text. Thus, we understand the process as an intertextual dialogism, considering that all forms of text are intersections of other texts (HUTCHEON, 2011). The results of the analysis show that the evil attributed to Nina in the novel can not be seen as essential, but stems from the interpretation of her actions by the gaze of others; with the erasure of these narrative voices (Friedman, 2002), in the film work, the character gains more space of subjectivation and the discourse on the evil attributed to it is smoothed, imprinting in the marksmanship of the director's poetics.

Keywords: Woman. Adaptation. Evil. Literary narrative. Filmic narrative.

\section{INTRODUÇÃO}

A prática de se adaptar obras literárias para o cinema começou ainda no século XIX, mas foi a partir do início do século XX (SKYLAR, 1975), que os críticos defenderam com mais intensidade a proximidade do cinema com a narrativa literária, por considerá-lo, também, "uma arte de contar histórias" (BORDWELL, 1997, p. 50). As convergências estéticas são evidentes, o que facilita, em alguns aspectos, o processo de tradução, entretanto, como

\footnotetext{
${ }^{1}$ Professora da Universidade de Fortaleza-UNIFOR. Doutora em Letras pela Universidade de Fortaleza. Pesquisadora nas áreas de Literatura Fantástica e Literatura e Cinema. E-mail: amlsampaio@yahoo.com.br
} 
se trata de relações sígnicas entre diferentes meios de linguagem, não é possível realizar uma cópia ou uma simples transposição de elementos.

Plaza (2001), tratando da tradução entre signos, assinala que o processo não objetiva obter consenso, mas, de modo diferente, visa atingir a essencialidade do signo. O teórico afirma, porém, que "a leitura para a interpretação é a interpenetração nas qualidades materiais do signo que delimitam os caracteres de seu Objeto Imediato" (PLAZA, 2001, p. 36). O diretor do filme é, dessa maneira, livre para fazer a escolha do que adaptar de um texto para o outro, de acordo com o seu estilo, os seus propósitos, ainda levando em conta o contexto histórico e social de ambos, que pode ser diferente. Assim, a tradução se dá "como processo de dupla semiose: uma leitura decodificadora e outra de inserção recodificadora” (CAMPOS, 2004, p. 22). A obra literária é, pois, adaptada para o cinema, sem que seja necessária a "fidelidade" da narrativa fílmica à literária.

Com efeito, Lefevere entende esse processo de tradução como um tipo de reescrita, que reflete uma ideologia e uma poética, que podem variar nos contextos de partida e de chegada, fazendo, em alguns casos, modificações no sistema da cultura receptora:

A tradução é, certamente, uma reescritura de um texto original. Toda reescritura, qualquer que seja sua intenção, reflete uma certa ideologia e uma poética e, como tal, manipula a literatura para que ela funcione dentro de uma sociedade determinada e de uma forma determinada. Reescritura é manipulação, realizada a serviço do poder, e em seu aspecto positivo pode ajudar no desenvolvimento de uma literatura e de uma sociedade. Reescrituras podem introduzir novos conceitos, novos gêneros, novos artifícios e a história da tradução é também a da inovação literária, do poder formador de uma cultura sobre outra (LEFEVERE, 2007, p. 11-12).

Nas palavras do autor, a tradução2 fílmica consiste numa reescritura, que modifica o texto de partida, introduzindo um novo olhar, refletindo, assim, a poética e a ideologia desse novo olhar, o que implica o desenvolvimento de uma outra obra. Assim, a personagem do texto literário pode, ao ser adaptada para o cinema, ganhar novos contornos, tanto em função de sua releitura, quanto ao novo contexto e à sua própria representação na tela.

Ao compararmos as personagens do livro às do filme, buscando suas especificidades, encontramos a declaração de Paulo Emílio Salles Gomes de que todas as considerações acerca dessa categoria no romance são válidas para o filme, "seja a narração objetiva de acontecimentos, a adoção pelo narrador do ponto de vista de uma ou mais personagens, ou mesmo a narração na primeira pessoa do singular" (GOMES, 1968, p. 103), embora o modo narrativo mais utilizado seja aquele em que o narrador se retrai e permite que as personagens se expressem e ajam por si mesmas. A personagem do romance, segundo o crítico, é feita exclusivamente de palavras escritas. Já, no cinema, a cristalização definitiva dessas personagens é condicionada a um contexto visual, ou seja, elas são encarnadas em 'pessoas'. Diz ele que "Essa circunstância retira do cinema, arte de presenças excessivas, a liberdade fluida com que o romance comunica suas personagens aos leitores" (GOMES, 1968, p. 111). Ou seja, o cinema, no caso da adaptação, na visão dele, não cria; limita-se a fazer um deslocamento de seres fictícios que já estão prontos e consagrados na literatura.

Não queremos discutir se há supremacia da literatura sobre o cinema nesse processo de adaptação, ou analisar em que sistema a personagem é melhor delineada, pois acreditamos que ambas as artes - literatura e cinema - influenciam-se reciprocamente (BAZIN, 1991 p. 84); até porque o aspecto visual da narrativa literária não retira da direção a

${ }^{2}$ Consideramos a adaptação como um processo de tradução, conforme discutido por Cattrysse (2014). Os dois termos, portanto, se alternarão ao longo da análise com sentido equivalente.

https://periodicos.unifap.br/index.php/letras

Macapá, v. 8, n. 3, $2^{\circ}$ sem., 2018 
necessidade de elaboração artística na construção das personagens no sistema cinematográfico. As leituras intersemióticas e as reescritas feitas pelo cinema a partir do texto literário não têm compromisso com fidelidade, pois não se limitam a uma simples "transposição de seres fictícios que já estão prontos e consagrados na literatura”, como defende Gomes (1968, p. 111). Há, nesse processo, uma evidente manipulação, que não é deliberada, ao contrário, se dá no sentido de lidar com aspectos estéticos ligados à poética dos dois sistemas.

É com base nesse escopo teórico que analisaremos a tradução da personagem Nina, protagonista do romance Crônica da casa assassinada (1959), de Lúcio Cardoso, para o cinema, em 1971, quando o cineasta Paulo César Saraceni fez a adaptação fílmica. Pretendemos observar se a maldade a ela atribuída pelas outras personagens foi representada na narrativa fílmica, analisando as estratégias utilizadas pelo diretor.

\section{A ADAPTAÇÃO E A PERSONAGEM CINEMATOGRÁFICA}

A adaptação é uma prática antiga, haja vista que as histórias nascem de outras histórias, assim como a arte deriva de outras já existentes, ou seja, é um processo sempre presente na criação artística da cultura ocidental, como assinala Linda Hutcheon:

[...] é evidente que as adaptações são velhas companheiras: Shakespeare transferiu histórias de sua própria cultura das páginas para o palco, tornando-as assim disponíveis para um público totalmente distinto. Ésquilo, Racine, Goethe e da Ponte também recontaram histórias conhecidas em novas formas. As adaptações são tão fundamentais à cultura ocidental que parecem confirmar o insight de Walter Benjamin (1992, p. 90), segundo o qual "contar histórias é sempre a arte de repetir histórias". Os ávidos adaptadores, ao longo dos séculos, certamente não precisaram dos pronunciamentos críticos de T.S. Eliot ou Northrop Frye para compreender o que, para eles, sempre foi um truísmo: a arte deriva de outra arte; as histórias nascem de outras histórias (HUTCHEON, 2011, p. 22).

Para a autora, a adaptação possibilita disponibilizar histórias para públicos distintos, o que propicia o alargamento do alcance da obra de partida. Ela enfatiza a importância da prática para a cultura ocidental e confirma que adaptar é recontar, o que corrobora a nossa ideia de que a personagem Nina, ao ter a releitura para as telas, mostra-se ao espectador frente a frente, por meio do discurso direto, de modo diverso do romance, em que ela é apresentada ao leitor mediante o discurso indireto, pelo olhar alheio. Além disso, ela é levada pelo cinema a um público que nem sempre tem acesso à produção literária de Lúcio Cardoso, expandindo, assim, os espaços de alcance de sua obra.

Voltando à relevância do diálogo entre o cinema com outras artes, é oportuno observar que essas misturas não implicam uma perda de identidade, mas o desenvolvimento dos gêneros. Depois de considerar que, ao buscar inspiração no texto literário o cinema se tornava impuro, André Bazin percebeu a adaptação - a passagem da escritura à imagem (BAZIN, 1991, p. 83) - como um modo de o cinema aperfeiçoar sua própria narrativa, sem perder a gramática que lhe é própria, ou seja, ambos os gêneros se beneficiam com as trocas e os diálogos que travam.

Com efeito, é incontestável a diversidade de temas que a literatura oferece ao cinema e as possibilidades de intersecção, que estão presentes na filmografia ou nos estudos dos precursores da arte cinematográfica. É conhecida a história do influxo do cinema do cineasta norte-americano Griffith na obra do escritor inglês Charles Dickens, de onde ele retirou 
"modelos narrativos, técnicas, uma concepção de ritmo e de suspense, articulando duas acções simultâneas e paralelas" (BELLO, 1997, p. 106) e fez o que Bello chamou de filme literário.

Paulo César Saraceni, seguindo o mesmo impulso, começou nos anos 60 a experiência de adaptar textos literários, dando visibilidade às personagens de Lúcio

Cardoso, especialmente à mulher, que aparece sempre como protagonista em seus

filmes. Assim, Nina, Ana (do romance Crônica), Donana de Lara e Sinhá (do romance O viajante) ganharam vida nas telas, demarcando o território feminino e adquirindo novos contornos com a releitura. Nina, por exemplo, é adaptada para o cinema caracterizada pela beleza, pela tristeza íntima e pela independência, sem ter sobre si mesma, entretanto, o mesmo discurso de ódio que a qualifica como má na obra literária.

Não pode ser a mesma, destarte, a configuração dos seres fictícios em ambos os sistemas, é certo. Especialmente nas narrativas fílmicas, as personagens são recortes, ou seja, aparecem apenas delineadas por um rosto e por atitudes que inferem sua personalidade. Não há, no filme, como no livro, espaço para a inteireza delas. Por mais que a narrativa literária tenha traços da narrativa contemporânea, no sentido de apresentar as personagens desenraízadas e o enredo fragmentado, há, nela, mais espaço para que elas se apropriem dos fatos. Nesse sentido, o romance Crônica é muito cinematográfico, haja vista a fragmentação do enredo em textos de narradores diferentes, que acabam por revelar os fatos de modo retalhado para o leitor e dando pouco espaço para a individuação das personagens, sobretudo porque o foco dos relatos é Nina; é sobre ela que há mais revelações, embora possamos projetar os outros pelo seu (deles) próprio discurso.

Como no filme é dada voz às personagens para se expressarem com palavras, olhares e gestos, o espectador acompanha visualmente a subjetivação delas, bem como a corporeidade, não tendo apenas que desenhá-las em sua imaginação, até porque ganham uma fisionomia. Vejamos o caso de Nina e Ana, que aparecem com os rostos das atrizes Norma Bengell e Tetê Medina, respectivamente, com toda a carga dramática de atuação, o que facilita a percepção da particularização de cada uma. Ana, sempre nervosa e cabisbaixa, com seu olhar de esgueira, é a própria encarnação da mulher dissimulada que, na maior parte do tempo, ganha ares de louca. Nina personifica-se pela exuberância dos trajes e dos cabelos longos e loiros, pela segurança do olhar que, em parte do tempo, perde-se em tristeza interior. Sua determinação e independência são flagrantes, destacando o contraste de sua presença na chácara, entre pessoas formais e soturnas, que olham para ela com um misto de admiração e reprovação. A maldade, que tantas vezes é imputada a ela na obra de Cardoso por meio dos relatos, se dilui, na tela, nos olhares de desconfiança e desaprovação.

\subsection{Nina e a sua reconfiguração na narrativa fílmica}

As personagens do filme Casa assassinada são caracterizadas como anjos, monstros e deuses de si mesmos (LAZO, 2012), com isso, ficando evidente a divisão maniqueísta entre bons e maus, personalidades autocentradas e imodestas, traços que evocam o orgulho e a superioridade que identificam a família Meneses.

Para construir o clima sombrio e nostálgico que envolve essas personagens, o início da narrativa do filme se dá com a presença do som do piano de Tom Jobim e a fotografia de partes da casa como pano de fundo. A contenção entre cores frias ${ }^{3}$ e exuberantes da

${ }^{3}$ Cores associadas ao gelo, à água, à lua, que transmitem a sensação de frio, como azul, violeta (roxo ou púrpura) e 
fotografia de toda a película dá um tom 'viscontiano' aos cenários (ORMOND, 2008), coadunando-se com a atmosfera misteriosa e tumultuada da casa e de seus moradores, exatamente como se apresentam no romance. $\mathrm{O}$ aspecto tão suntuoso quanto mal cuidado aparece em várias cenas, com focalizações em paredes envelhecidas e portas retintas, como a deixar clara, nas imagens, a negligência e a falta de gestão do patrimônio, harmonizando-se, assim, a decadência do espaço físico com o declínio dos seus moradores, o que faz com que a casa apareça, qual está no livro, como elemento representativo da destruição.

Tanto na narrativa literária como na fílmica, a história começa a ser contada pelo desfecho. O livro se inicia com uma narração do diário de André, em que ele fala dos sentimentos em relação à morte de Nina e conta sobre a última visita ao quarto dela. No filme, o corpo da personagem é focalizado em cima da mesa da sala, vestido de preto, e logo surgem as cenas de André (Augusto Lourenço) visitando-a no quarto. Seguem-se os relatos, com a narração em voice over, e as cenas que recompõem a sua história na casa dos Meneses, até o desfecho, que é a retomada do velório que apareceu no início. Embora se apresentem os mesmos procedimentos, os propósitos são diferentes: enquanto no romance revela-se o destino das outras personagens, no filme, o epílogo se dá na retomada do velório. A esse respeito, Carelli assinala:

A primeira metade do romance é mais complexa em seu arranjo de temporalidade do que o fim da obra. A narrativa se estrutura após uma abertura em torno de um arco que se fecha no capítulo 55. A morte de Nina constitui o tempo presente (no passado), o corpo do romance apresenta o antes, o fim da narrativa de Valdo e o último capítulo falam do depois (CARELLI, 1988, p. 185).

Assim como no livro, a estruturação do tempo, no filme, é complexa. Ele se inicia, repisamos, com a exibição do corpo de Nina sobre a mesa da sala, vigiada por André. Logo após, recupera-se um momento cronologicamente anterior, em que ela está deitada em sua cama, abatida e impaciente, falando com André num quase delírio de salvação.

Para o leitor, tudo é passado, mas ele percebe que o tempo diegético compõe uma história cíclica, montada a partir de excertos retirados do passado e outros escritos no presente, numa visita à memória. O espectador do filme, por sua vez, percebe que a história se inicia no passado, quando, após a cena em que Nina já aparece morta, começa o flashback com a personagem ainda viva. Somente no final do filme o velório é retomado para a conclusão do desfecho iniciado logo nas primeiras cenas.

A narrativa do filme é construída por meio de recortes de passagens da obra, com subtrações de elementos e fatos, bem como com alterações. Britto (1996, p. 21-22), ao tratar dessa adaptação, traz uma discussão que reforça essa estratégia de Saraceni. Para o autor, como o romance tem uma duração mais extensa que a do filme, na adaptação, é muito comum o processo de redução de elementos e personagens para diminuir o tamanho da obra. Dessa forma, no filme de Saraceni, há subtração de trechos muito digressivos, sobretudo de momentos introspectivos de alguns personagens, além de cortes de personagens, diálogos e cenários. Quando Nina, por exemplo, aparece no quarto, já em fase avançada da doença, não há, como no livro, um médico carioca de plantão na sua cabeceira; somente Betty (Leina Krespi) é a responsável pelos cuidados. Nessa cena do filme, a ausência do

verde.

${ }^{4}$ Com influência estética nostálgica do cinema do italiano Luchino Visconti. 
médico pode ser vista como um modo de marcar o descaso da família com ela. Por se tratar de um momento da narrativa em que o leitor se depara com um quadro dramático em que a doença é colocada em foco, como o médico é responsável pelo exame no corpo apodrecido de Nina e pelos detalhes da situação, é provável que o diretor tenha desejado, também, evitar os pormenores escatológicos na tela.

Outro ponto de diferença na reconfiguração da personagem merece destaque: ela é velada vestida de preto, descalça, com as mãos atadas e não apenas envolta num lençol como aparece no livro. Ao não optar pelo lençol branco, o diretor diluiu uma simbologia de cunho religioso por nós observada no livro, que seria a associação do lençol ao pano que cobriu o corpo de Jesus Cristo para o sepultamento.

Interpretamos essa mudança como uma escolha de evitar tocar em questões religiosas e até traduzir o símbolo litúrgico usado por Cardoso, o que dá à narrativa fílmica um tom mais ímpio. Entendemos que, ao assim proceder, Saraceni parece evitar, na narrativa fílmica, questionamentos religiosos, recorrentes na obra de Cardoso, tanto na voz de Ana como na de André, e, nesse sentido, evitou a fixação do símbolo que recorre a associações cristãs.

Ao optar pelo uso da roupa preta em lugar do lençol branco, o filme reforça o apagamento do estilo pessoal de Nina para a incorporação do estilo do vestuário da família. Se, no romance, ela jaz totalmente desprovida da vaidade e da ostentação que caracterizavam sua indumentária, no filme, esse aspecto ganha maior ênfase, pois, com a evidente predominância do signo visual, temos o poder da imagem que, mais que representar as coisas, as invoca, como assegura Neiva Jr. (1994):

As coisas representadas não explicam a imagem; esta é aquilo que a invoca. A lógica da imagem exige que sua representação seja feita a partir desse esquema que reformula a experiência visual. Se a nomenclatura antecede a representação, a imagem é, por natureza, autônoma; sua autonomia é restrita e contrabalançada pela necessidade de assimilá-la ao objeto [...]. A imagem adquire, então, a faculdade possível de apontar para as coisas (NEIVA JR, 1994, p. 12-13).

$\mathrm{Na}$ fala do autor, a palavra antecede a representação. O que na obra literária é palavra que fomenta a idealização, na tela é imagem que aponta para as coisas. Assim, a figura de Nina vestida de preto suscita uma leitura de desconstrução de sua imagem na tela, que é sempre apresentada com roupas leves e coloridas, cabelos soltos e postura liberta, quando viva; depois de morta, ela é velada de preto, com uma imagem austera que não condizia com a sua maneira de ser. As mãos atadas sugerem para o espectador o estigma do domínio, do controle que os Meneses nunca conseguiram ter sobre ela e que, nessa situação, fazem questão de mostrar que obtiveram, que foram, enfim, vitoriosos no combate travado com a personagem.

Outra estratégia importante de construção da narrativa fílmica é a forma como a família Meneses vai aos poucos, por meio dos relatos que sucedem o velório, se apresentando nas cenas iniciais. Após vermos Nina morta, na solidão da sala, e depararmos, na sequência, com sua figura moribunda conversando com André, inicia-se uma cena em flashback com conversas entre Betty e Timóteo (Carlos Kroeber), que se alonga e traz o momento da chegada de Nina à chácara. $\mathrm{Na}$ cena em questão, aparece a charrete parada na frente da casa, e Demétrio (Nélson Dantas), Ana, Valdo (Rubens de Araújo) e Betty esperando-a no alpendre, com os criados à espreita. É a partir desse ponto que os Meneses vão se mostrando para o espectador com suas características típicas de uma família que conserva valores tradicionais, ostentando luxo mesmo quando já quase nada possuem. Ao falar sobre 
essa questão, Ormond comenta a forma como a família é configurada no filme: "tipos espectrais, folclóricos, sombrios, [que] vivem numa dupla-face entre o desequilíbrio existencial - que inclui religiosidade e hipocrisia das velhas famílias mineiras - e o lado onírico, que desemboca na multiplicidade de narradores, alegorias e cortes temporais" (ORMOND, 2008).

Assim, ensimesmados em seu mundo conflituoso, tanto no filme quanto no romance, as personagens são mostradas como presas às tradições dos antepassados, como capazes de dissimular seus desejos, encobrir suas faltas e proteger o seu mundo em disfarces que não se sustentam e acabam por desmoronar.

O figurino do filme caracteriza de forma precisa cada um desses membros da família, ressaltando os traços peculiares de cada uma: Ana aparece sempre com roupas muito sérias e bicolores, Timóteo está sempre vestido com roupas femininas extravagantes, Valdo e Demétrio apresentam-se sempre de paletó, e Nina surge na tela sempre glamurosa e cheia de cor, o que reforça o nosso argumento sobre o contraste com o seu figurino ascético depois de morta. A esse respeito, Ormond (2008) acrescenta que o figurino e a fotografia, na tela, alcançam "vigor muito maior que o do roteiro, que trabalha com a ingratíssima tarefa de adaptar para o cinema uma obra perfeita e talhada em outro universo, o literário, vasto por si só" (ORMOND, 2008). De fato, se a vastidão da obra torna difícil a tarefa da adaptação de seu complexo enredo, não acontece o mesmo em relação aos detalhes físicos das personagens que ganham vida nas telas a partir do realce da indumentária.

A adequação da narrativa literária ao novo meio requer, por conseguinte, muitas modificações. O sistema receptor igualmente interfere no processo de tradução, pois não se pode desconsiderar o público-alvo nem se eximir de corresponder às expectativas da cultura de chegada (TOURY, 1995, p. 53). No caso de Saraceni, acreditamos que as subtrações se deram, primordialmente, em função do que considerou Brito - a adequação ao tempo da narrativa fílmica -, já que o romance é bastante extenso. Mas não se pode desconsiderar também a opção de um redirecionamento do foco da narrativa, já que os questionamentos acerca de Deus, que estão no texto de Cardoso, não conduzem a poética do diretor. Não aparece na tela a cena em que André conversa com Valdo, querendo saber se há ressurreição, mostrando a sua descrença no ser supremo, por ter dele tirado a pessoa que mais amava, chegando a cuspir no cadáver de Nina. Essa situação é importante para que o leitor compreenda a inquietação com os ensinamentos católicos, que constitui um traço fundamental na obra de Cardoso, mas, no filme, não acontece, o que reforça a nossa ideia de que Saraceni evitou levar à tela a angústia espiritual sempre tão nevrálgica nos enredos do escritor.

Além disso, provavelmente, o objetivo de retratar a mulher Nina, numa outra perspectiva, pode ter sido no sentido de dar a ela mais espaço para a subjetivação, para que ela se mostre e o espectador possa, por meio de seu comportamento (atuação), corroborar ou refutar a mácula de maldade que as vozes narrativas do romance legam a ela.

Qualquer que tenha sido a razão das escolhas, como resultado dessa reconfiguração, parte das histórias do romance ficou fora do filme, bem como as vozes de algumas personagens foram suprimidas. Não são poucos os cortes. Na conversa que Valdo tem com Nina sobre André, pedindo que se afaste, mostra-se a desconfiança dele sobre a possibilidade de incesto, mas o seu discurso atribuindo perversidade a ela e uma natureza corrosiva que, no livro, aparece nas confissões ao padre, fica subtraído da narrativa fílmica. Do mesmo modo, as narrativas do Padre falando de um mal atávico arraigado à própria estrutura da casa e as que o médico conta, falando do mal que vem dos antepassados dos Meneses são omitidas. 
O conteúdo das cartas de Valdo ao Padre e à própria Nina, em que ele realça a presença de um mal inerente à natureza dela, igualmente, não aparece no filme, bem como a passagem do diário de Betty, em que ela diz perceber que a patroa é a causadora de todo o desequilíbrio na casa.

Entendemos que esses cortes dizem respeito à escolha deliberada do diretor pela não associação da personagem ao mal. Diferente da personagem no livro, a Nina que o filme de Saraceni representa caracteriza-se pela transgressão e pela independência. Embora sem acomodação ao ambiente da casa dos Meneses, ela não é submetida permanentemente a julgamentos e comparações que a associam a uma pessoa maligna.

A eliminação de personagens e detalhes do livro, no filme, dá novo enfoque à construção da narrativa, trazendo algumas implicações para o público receptor. No que se refere à Nina, a ausência do Coronel significa o silenciamento sobre o seu passado. No filme, não há nenhuma referência sobre a sua origem nem ao seu pai, um militar viciado em jogo, que a perde numa aposta para o Coronel. Não há detalhes sobre o fato de que o Coronel foi apaixonado por ela e custeou muitos dos seus luxos; nem sobre a sua mãe, uma atriz italiana que cedo voltou para o seu país, deixando o marido e a filha. Também não se sabe a circunstância em que Valdo a conheceu, apenas é dito que os dois se encontraram no Rio, como Nina conta ao médico na noite da tentativa de suicídio do marido. Quem assiste ao filme a conhece já como esposa de Valdo, chegando à Chácara e se sentindo enganada em relação ao poder aquisitivo dele, quando Demétrio diz que a família está falida.

O farmacêutico, que representa, no livro, a conexão dos Meneses com a cidade de Vila Velha, também está ausente da adaptação. As suas narrativas, no romance, dão conta tanto das confidências que os irmãos fazem a ele na farmácia, quanto da opinião que ele tem sobre a família. No que respeita à Nina, é ele quem narra a chegada dela à cidade pela primeira vez, a expectativa do povo para conhecer a moça da cidade grande que desposara o caçula dos Meneses, faz descrições sobre sua beleza ímpar e, depois, emite a opinião mordaz do povo sobre a sua conduta. Podemos dizer que a ausência de sua voz implica o apagamento da opinião da cidade sobre o casamento de Valdo e Nina, bem como suas opiniões sobre o que transcorria no interior da chácara e o que falava o povo da cidade sobre Nina particularmente, o que evidencia, mais uma vez, um modo de não dar relevo a atitudes de julgamentos a respeito da personagem.

Percebe-se a intenção por parte do diretor de omitir o passado de Nina no Rio de Janeiro, sua origem familiar e a maneira como vivia. Embora se perceba, na película, que ela é uma mulher imodesta, acostumada ao luxo e às festas, que nunca trabalhou nem teve formação para ser esposa e dona de casa, e que esperava, com o casamento com o fazendeiro mineiro, ter a segurança de arrumar a sua vida depois de órfã, só se desconfia do seu passado, por meio da fala agressiva de Valdo, que se reproduz na tela, tal qual está na obra literária, dizendo que se casou com uma prostituta.

A transformação no comportamento de Nina quanto à vaidade é também observada, no filme, após a doença. Como no livro, no filme, ela queima os vestidos que representam a vida de festas e glamour que levava na capital. Na narrativa literária, como já apontamos, ela viaja ao Rio, a pretexto de uma consulta médica, e se encontra com o Coronel, a quem pede chapéus e vestidos de luxo, embora já tenha o diagnóstico fatal. No filme, em outra perspectiva, ela sequer faz essa última viagem. Esse pormenor relevante para a compreensão dos seus caprichos é subtraído, isentando-a de conjecturas por parte do público acerca de sua suposta leviandade.

A personagem do Coronel, embora só tenha um relato na obra literária, é uma figura 
importante na história de Nina. Além da presença dele em sua juventude, ele, mesmo a distância, permanece como o seu apoio. É a ele que ela pede ajuda quando trai o marido e volta a morar no Rio durante longos anos. No filme, esses detalhes sobre sua interação com Nina não têm quase relevância, aparece apenas num pensamento dela exposto em voice over.

Esses procedimentos corroboram a visão de Hutcheon (2011, p. 8) sobre a adaptação fílmica não apenas como uma entidade formal, mas também como um processo que sofre interferências de natureza humana e, como tal, de subjetividades. Ou seja, Saraceni não prolongou as cenas de exacerbada vaidade de Nina, comprando compulsivamente objetos de luxo às vésperas da morte nem seu envolvimento ambíguo com o militar; o ciclo de vida dela encerrou-se na chácara, dias após a queima dos vestidos, marcando um ritual de passagem e aparente purificação da personagem.

Outro aspecto importante na composição da narrativa do filme é o modo como os acontecimentos se desenvolvem. No livro, eles são descritos, como já referimos, em diários, depoimentos, confissões e cartas; no filme, as ações, adaptando-se ao novo meio, aparecem diretamente na tela. Para tal, a direção optou por apresentar diálogos ao espectador, intercalando-os com digressões que, no filme, as próprias personagens fazem em seus relatos, por meio de narração em voice over.

Ocorre, constantemente, a adaptação dos discursos direto e indireto livre para o discurso direto na tela, o que constitui um modo de adequação cênica, uma forma de facilitar a apropriação das alocuções pelas personagens, já que a fala, de fato, a elas pertence. As mudanças significativas de que falamos se deram, certamente, pela impossibilidade de manter a narrativa sob o ponto de vista das diversas personagens. As mesmas situações e a visão que elas têm da protagonista foram distribuídas nos diálogos, o que fez com que muitos textos e algumas personagens fossem apagadas, como assinalamos.

\section{Lipão}

O cinema, pelo menos nos termos de sua narrativa clássica, é um sistema de linguagem que depende mais da palavra falada do que da escrita, devendo, portanto, ser mais dinâmico e sucinto do que o livro. A palavra escrita do livro é transformada em imagem em movimento; a predominância dos signos verbais passa a ser dada aos signos não verbais.

$\mathrm{Na}$ narrativa fílmica, as vozes que, no romance, se alternam, com cada personagem expressando a sua versão da história de Nina, perdem a perspectiva individual e são distribuídas em diálogos entre as personagens ou em narração em voice over para expressar pensamentos. $O$ texto escrito comporta essa fragmentação de narradores sem perder a unidade do enredo; já a narrativa cinematográfica tem seus próprios códigos de interação com o espectador, e eles diferem dos códigos do livro na relação com o seu leitor, como afirma Araújo:

Enquanto um romancista tem a sua disposição a linguagem verbal, com toda a sua riqueza metafórica e figurativa, um cineasta lida com pelo menos cinco materiais de expressão diferentes: imagens visuais, a linguagem verbal oral (diálogos, narração e letras de música), sons não verbais (ruídos e efeitos sonoros), música e a própria língua escrita (créditos, títulos e outras escritas). Todos esses materiais podem ser manipulados de diversas maneiras (ARAÚJO, 2011, p. 23).

Vê-se que a manipulação operada na obra literária ao ser reescrita faz parte do processo

https://periodicos.unifap.br/index.php/letras

Macapá, v. 8, n. 3, $2^{\circ}$ sem., 2018 
de recriação. Ambos os sistemas têm as suas subjetividades e projeções imagéticas que podem ser, naturalmente, diversas. Além disso, enquanto o texto escrito dispõe dos olhos e da imaginação do leitor, o filme, além da fotografia e dos diálogos, apresenta os efeitos sonoros, a sonoplastia e toda a "riqueza metafórica figurativa" (ARAÚJO, 2011, p. 23) de que pode dispor o texto nesse novo meio.

Sobretudo, não há como reproduzir o projeto estético de uma obra escrita para a tela. Se Cardoso usou como estratégia de construção do romance a presença de uma figura misteriosa que compilou textos e colheu depoimentos de pessoas que, direta ou indiretamente, passaram pela vida de Nina, o diretor do filme, certamente, não pôde lançar mão do mesmo recurso, até mesmo porque tal estratagema, talvez, não tivesse a mesma significação e o mesmo impacto no meio cinematográfico.

$\mathrm{Na}$ narrativa fílmica, a primeira conversa de Nina com Valdo, após a chegada dela à chácara, se dá no jardim e ela está segurando um buquê de violetas, sugestivamente dadas a ela pelo marido, a quem diz serem as suas flores preferidas e a quem pergunta sobre a pessoa que cuida do jardim. No romance, Valdo presenteia-a com dálias e, em outro momento, ela olha as violetas no canteiro, em companhia da governanta; é a ela que diz da sua predileção por aquelas flores e pergunta quem cuida do jardim. Toda essa composição é retirada do diário de Betty. No filme, a voz da personagem-narradora desaparece e quem assume o comando é a câmera, última categoria narrativa de Friedman (20020, então deslocada do texto literário para a tela. Esse foco significa o máximo em matéria de "exclusão do autor" e serve às narrativas que tentam transmitir flashes da realidade como se apanhados por uma câmera, arbitrária e mecanicamente; na verdade, não servem a essa realidade, mas a traduzem para as telas.

De acordo com Friedman, "A câmera não é neutra", pois que existe alguém por trás dela que seleciona e combina, pela montagem, as imagens a mostrar. Há, portanto, um ponto de vista onisciente dominando tudo, ou o ponto de vista centrado numa ou várias personagens. Assim, quem toma o comando da narração fílmica é o diretor, que assume a vOz ao selecionar.

Consideramos, ainda, que, na narrativa do romance, todos os narradores são testemunhas (com exceção de Nina, cujas cartas são autorreferentes evidentemente); já na narrativa fílmica há uma espécie de Onisciência seletiva múltipla (Multiple selective omniscience) (FRIEDMAN, 2002, p. 179), ou seja, perde-se o “alguém” que narra, não há propriamente narrador, já que a história vem diretamente das personagens, das falas e impressões que os fatos e as pessoas deixam nelas.

Quando é dada a voz aos pensamentos da protagonista, Nina entra em cena com a narração em voice over, e é como se estivéssemos ouvindo suas cartas em voz alta enquanto olhamos seu semblante na tela. Ela apenas fala trechos de uma das cartas ao Coronel. O conteúdo das que foram enviadas a Valdo, a sua defesa sobre o adultério de que foi acusada, não aparece.

Nessa situação, verificamos a presença da Onisciência seletiva, uma categoria semelhante à anterior; a diferença é que, em vez de várias, temos uma só personagem, tem-se um centro fixo. $O$ ângulo é central, e os canais são limitados aos seus sentimentos, pensamentos e percepções, que são mostrados diretamente. Essa técnica se aplica a alguns romances, quando se usa o recurso do fluxo de consciência, mas se adapta mais perfeitamente à adaptação dele para as telas.

Há, no texto cinematográfico, uma espécie de eliminação do autor do livro, pois que se foca no Modo dramático (The dramatic mode) (FRIEDMAN, 2002, p, 178); tem-se a voz 
dos narradores diluída nas falas e nas ações das personagens, que falam com algumas notações de cena conectando os diálogos. No caso da interpretação de Nina das suas próprias cartas constantes do livro, o discurso aparece como pensamento, com a voz da personagem, como afirmamos, em narração em voice over. O tom de voz e a interpretação fisionômica da atriz, bem como os planos aproximados, ou seja, o foco da câmera diretamente no rosto da personagem, conferem maior carga dramática ao conteúdo.

Embora a técnica da narração em voice over seja mais usada em documentários, quando a voz da personagem do texto de partida é ouvida para aferir mais credibilidade à tradução, Saraceni optou por mostrar o rosto de Nina, enquanto sua voz conta os fatos. A escolha do cineasta por esse recurso, nesse momento do texto fílmico, pode ter sido para inserir um conteúdo que, de outro modo, só faria sentido se a personagem do Coronel estivesse presente na narrativa fílmica. Como tal personagem não aparece e tem relevância em determinado contexto da vida de Nina, pelo menos a referência a ele foi necessária.

A presença do rosto de Nina, em primeiro plano na tela enquanto sua voz ressoa, torna mais pungente a fala e mostra uma de suas características: desligar-se do real e perder-se em seus pensamentos. Silva aponta que, no cinema de ficção, a narração em voice over tende a aparecer nos momentos em que se apresentam os monólogos interiores das personagens. Diz Silva: "O voice over é, normalmente, usado para lidar no cinema com a apresentação de processos mentais" (SILVA, 2007, p. 153). De fato, se verificarmos o rosto de Nina durante a narração, perceberemos o sentido de introspecção e deslocamento da realidade referencial em que a personagem se encontra como em estado de devaneio.

Kozloff (1988) distingue narração em voice over de outros tipos de voz over. Ele entende as narraç,ões em voz over como: "declaraç,oes orais que dizem respeito a qualquer porção de uma narrativa, proferidas por uma entidade que nao e vista e que se situa em um espaç, e em um tempo que ficam fora daqueles simultaneamente apresentados pelas imagens na tela"5 (KOZLOFF, 1988, p. 5). No caso do filme de Saraceni, o rosto de Nina está presente na tela, mas é como se ela estivesse ausente, alheia em seus pensamentos. Ela fala em voice over para preencher um espaço vazio, inserir na história uma personagem que não aparece, cuja presença é evocada em forma de pensamento para que o espectador tome conhecimento dela.

Outra forma de lidar com a voz no filme é através do uso de Onisciência seletiva. Um exemplo dessa situação está nas cenas em que Ana se dirige ao Padre Justino para fazer a sua confissão, contando como se moldou, desde menina, para casar-se com Demétrio. Embora apareça na tela a capela da Chácara e haja a presença do vigário, a personagem anda pelo jardim, enquanto seus pensamentos são apresentados por meio de narração em voice over. Quando ela encontra Nina tomando sol, a técnica de voice over é substituída por um diálogo, depois é retomada, e sua voz narra trechos da confissão em que conta sobre sua curiosidade doentia sobre Nina. Essa mudança imprime mais emoção à cena, prendendo o espectador à voz cujo tom traduz o estado do espírito nervoso e arrebatado da personagem que fala. Outro exemplo do uso desse recurso se apresenta por ocasião da conversa de Nina com o médico, no jardim, após a tentativa de suicídio de Valdo. A personagem do médico não aparece; somente Nina é focalizada, embora se escute a voz do seu interlocutor. Sua voz é apressada e nervosa. Assim, os discursos dos relatos da obra literária vão sendo

${ }^{5}$ Tradução de Arthur Wolff Hack. In: A voz over como instrumento narrativo. 2014. Disponível em: < https://www.lume.ufrgs.br/bitstream/handle/10183/111778/000952781.pdf?sequence=1>. Acesso em: 20 ago. 2017.

https://periodicos.unifap.br/index.php/letras Macapá, v. 8, n. 3, $2^{\circ}$ sem., 2018 
diluídos na voz das personagens, adequando-se à atuação cinematográfica e sendo, portanto, bastante reconfigurados.

Quanto à Nina, diferente do livro, em que ela pouco tem espaço de fala, embora todas as narrativas sejam a seu respeito, no filme, ela assume diretamente o prota-

gonismo. A voz dos que fazem os relatos sobre ela, no livro, tendem, quase invariavelmente, a apontar o seu comportamento dúbio e a associá-la ao mal que recai sobre a casa. No filme, como os textos são mais curtos e a maior parte deles se transforma em fala, nota-se que a personagem tem, sim, um comportamento diverso dos demais da chácara, que há olhares de censura, mas que não se agrega ao discurso a sua capacidade de destruição e a associação ao mal. Apenas na relação com Ana as alocuções de ódio são exploradas.

\subsection{A suavização do ódio e da associação ao mal}

Sabe-se que o romance Crônica foi escrito nos anos 50, período em que a mulher ainda passava do poder do pai para o do marido, devendo-lhe obediência. Ao transgredir essas regras, ela se tornava imediatamente "amaldiçoada". Nos anos 70, contexto da adaptação da obra, a mulher começou a entrar no mercado de trabalho (BRUSCHINI, 1994) por conta da deterioração dos salários, o que a levou à necessidade de complementar a renda da família, também por conta do aumento da expectativa de consumo propiciado por novos produtos no mercado. Isso deu a ela mais liberdade e autonomia, minimizando, assim, os efeitos maléficos de suas transgressões.

Houve, nessa conjuntura, "profundas transformações nos padrões de comportamento e nos valores relativos ao papel social da mulher, intensificadas pelo impacto dos movimentos feministas e pela presença feminina cada vez mais atuante nos espaços públicos" (BRUSCHINI, 1994, p. 179-180). Aliado a essa mudança pode-se mencionar o acesso das mulheres às universidades.

Embora Nina esteja à margem de todo esse processo, pois nunca trabalhou e sempre viveu a custa, segundo os relatos, de favores dos homens, a construção do seu perfil no cinema está mais ligado à angústia e ao comportamento transgressor; não se flagra, no texto fílmico, manifestações verbais de que ela é naturalmente má, mesmo que, em alguns casos, seja mostrada como propulsora de conflitos. Se Cardoso, nos anos 50, mostrou a situação desse tipo de mulher - soberana e voluntariosa - numa cidade do interior, julgada pelos que com ela convivem como uma bruxa ou um demônio, denunciando o modo como a sociedade a via, Saraceni, embora não a transforme numa pessoa com características de bondade explícita, retoma o seu comportamento fora das regras sociais, mas, de certa forma, suaviza o poder de destruição que é a ela atribuído pelos que contam a sua história no livro.

Nesse sentido, houve mudanças com relação ao texto de partida que se insere numa nova poética. Lefevere (2007), tratando dessas mudanças, as apresenta divididas em três categorias: (1) pessoal, (2) pessoal + ideológica e (3) ideológica. Evidentemente, ao adaptar uma obra literária para o cinema, como não é possível manter a total equivalência por tratarem-se, reiteramos, de signos com poéticas diferentes, há uma escolha dos núcleos a serem enfatizados. Comentando sobre o que inspira as reescrituras, o autor adverte que elas decorrem de motivações (ou restrições) ideológicas ou poetológicas:

Se algumas reescrituras são inspiradas por motivações ideológicas, ou produzidas sob restrições

https://periodicos.unifap.br/index.php/letras

Macapá, v. 8, n. 3, $2^{\circ}$ sem., 2018 
ideológicas, dependendo da identificação ou não do reescritor com a ideologia dominante de sua época, outras reescrituras são inspiradas por motivações poetológicas, ou reproduzidas sob restrições poetológicas (LEFEVERE, 2007, p. 22).

Se pensarmos nesses termos, as escolhas de Saraceni podem ser analisadas mais pelo ponto de vista de identificação poetológica do que ideológica; ele era admirador da obra e do estilo "monumental" do escritor mineiro, chegando a elogios declarados em sua autobiografia Por dentro do cinema novo (1993). A identificação ideológica é parcial, haja vista que sua forma de denúncia da situação da mulher é diferente, bem como o modo de tratar o tema da morte: enquanto Cardoso dá voz para que as personagens avultem seus questionamentos sobre a existência de Deus, Saraceni silencia. Observaremos, também, que a personagem Nina é construída sob um novo olhar, em que o sentimento de culpa dela cobrado sofre restrições, o que mostra uma tradução sem qualquer preocupação com fidelidade.

Percebemos, claramente, a intenção de 'enxugar' a trama, para torná-la mais cênica e menos loquaz, já que os textos do romance são extensos e digressivos como o são normalmente as cartas, depoimentos, diários, confissões e relatos confessionais em geral. Muitos cortes ocorrem até mesmo de frases que se alongam em sua apresentação, por meio da técnica do fluxo de consciência, como confirma a análise de Ormond (2008): “A poética do livro é difícil de ser verbalizada naturalmente pelos atores. As frases longas nem sempre soam casadas com os conflitos visuais". O espectador que leu o livro antes de assistir ao filme reconhece trechos da narrativa, mas não tem a impressão de estar "folheando as páginas do livro", como ocorre, por exemplo, em Lavoura Arcaica (2001), de Luiz Fernando Carvalho, em que o sermão do pai à mesa é reproduzido na íntegra ${ }^{6}$ na tela. $\mathrm{O}$ corte de muitas passagens do livro de Cardoso também decorre da escolha pessoal do diretor. Como defende Hutcheon (2011), o ato interpretativo de apropriação de uma obra envolve a natureza humana, as subjetividades do interpretante.

A atenuação da associação da protagonista ao mal parece evidente no filme. Na narrativa literária, quase todas as personagens, quando se referem à Nina, fazem menção ao seu poder destrutivo. No filme, Valdo, num primeiro momento, demonstra os seus ciúmes e desconfia da mulher, mas a sua fala em relação à sua maldade, em situações posteriores, é suprimida. Demétrio mostra, através do olhar do ator que representa a sua personagem, o seu amor reprimido, mas não vocifera contra a cunhada. André demonstra a sua paixão e a sua insegurança, como na narrativa literária, mas o discurso em que refere o seu veneno, a sua maldade, e até a compara a anêmonas-do-mar, não aparece na tela.

Nina, por sua vez, manifesta uma angústia secreta, uma insatisfação existencial, que é reforçada por meio da interpretação visceral da atriz Norma Bengell; Betty é a governanta preocupada, conciliadora e protetora do frágil André, mas demonstra-se sempre preocupada e disposta a compreender a patroa. Ana é um ser fechado em si mesmo, frustrado e incapaz de qualquer ato de amor; ela, sim, continua a ver maldade nas atitudes da cunhada.

Por meio da reação dessas personagens, fica evidente que Nina representa a transgressão naquele espaço de reprodução dos valores patriarcais, a ruptura com a tradição, visto que toma suas próprias decisões, viaja sozinha, veste-se com exuberância e sensualidade, não exerce as suas funções de esposa e mãe, por isso representando o mal para os que com ela convivem e dela esperam outras atitudes. Mas não há palavras, ao longo do filme, que a

${ }^{6}$ Lavoura Arcaica (2001), filme de Luiz Fernando Carvalho, adaptado da obra homônima (1989), do escritor paulista Raduan Nassar.

https://periodicos.unifap.br/index.php/letras Macapá, v. 8, n. 3, $2^{\circ}$ sem., 2018 
descrevam como um ser demoníaco como ocorre no livro.

Reforçando a diferença da narrativa fílmica com relação às narrativas do livro, não existe também referência ao fato de ela não ter consciência da própria maldade, que está presente na fala de algumas personagens do livro. Se, na obra escrita, vemos referência a ela como dona de um mal essencial, comparações explícitas a bruxas que foram queimadas na Inquisição, poder de sedução comparado à feitiçaria e referência ao seu veneno e à sua capacidade de destruição, no filme, observamos que a personagem se revela por meio de sua representação: olhares, falas, atitudes, já que ela está delineada diante do público como um ser vivo, embora fictício e preso numa tela.

\section{CONSIDERAÇÕES FINAIS}

Como é possível observar, o clima de decadência e decomposição que caracteriza a família Meneses, no livro, é transmutado para o filme, bem como certo desdouro com a imagem da mulher da cidade grande. Ana, personagem aparentemente secundária, figura como um elemento importante na construção de Nina e da própria imagem da mulher cardosiana, que se rebela contra o seu fado. Assim, ao construir personagens tão complexas, o romance reafirma um período marcado pelo apogeu da subserviência feminina. Ana representa essa figura moldada para o casamento que, ironicamente, resulta numa deformação. Já Nina tenta romper com esse padrão.

$\mathrm{Na}$ adaptação da obra, embora Saraceni traduza as mesmas características da época em que o romance foi escrito, no contexto de produção do filme, a mulher já tinha abertura para lutar pelos seus espaços. Nina, desde o contexto do romance, já entendia tudo como natural e queria viver livremente, o que chocava Vila Velha e provocava o julgamento das pessoas da cidade. Essa atitude, entretanto, não chocava o público dos anos 70 , que convivia com a atitude revolucionária de Leila Diniz, atriz que mais rompeu barreiras e se afirmou na sociedade preconceituosa daquela época, e com o advento dos movimentos feministas que questionavam o lugar historicamente reservado à mulher nas sociedades patriarcais. Nina é, portanto, no filme, uma espécie de Leila fictícia, um pássaro que não aprendeu nem aprenderia nunca a viver preso; daí, se poderia explicar o discurso de ódio mais arrefecido para o espectador.

Saraceni, desse modo, lança o seu olhar sobre a obra literária de Cardoso e a traduz para o cinema com a inserção das suas próprias crenças, seus objetivos e seu estilo, procurando adaptá-la ao contexto de chegada. Ao assim proceder, ele dá ao filme uma autonomia que lhe é devida independente da obra que o originou.

A morte de Nina acontece no romance de Cardoso tal como ocorreu com personagens emblemáticas do século XIX, como Emma Bovary (1956), de Flaubert, Anna Karenina (1877), de Tolstói e Luísa, de Eça de Queirós (1878). No filme, entretanto, Saraceni parece diminuir a extensão da via crucis de Nina e as dores do seu calvário, o que representa uma espécie de atenuação da pena imputada à mulher adúltera, haja vista a diferença de contextos de produção e recepção, bem como a atualização da visão de mundo da sociedade em relação ao fato.

\section{REFERÊNCIAS}

ARAÚJO, Naiara Sales. Cinema e literatura: adaptação ou hipertextualização. Revista Littera. Universidade Federal do Maranhão. n. 3, p. 6-23, jan./jul. 2011. Disponível em:< 
http://www.periodicoseletronicos.ufma.br/index.php/littera/article/_ view/ 449/272>. Acesso em 06 abr. 2016.

BAZIN, Andre. O cinema. Tradução de Eloisa de Araújo Ribeiro. São Paulo: Brasiliense, 1991.

BELLO, Maria do Rosário Lupi. Quarto com vista sobre a cidade: ponto de vista sobre um filme "literário". Discursos. Coimbra, 11-12, p. 105-109, 1996-1997. Dis-

ponível em: <http://repositorioaberto.uab.pt/bitstream/10400.2/4031/1/Maria\%20do\%20Ros\%c3\%a1rio\%20Lupi\%20Bello.pdf>. Acesso em: 29 abr. 2017.

BORDWELL, David. On the History of Film Style. Cambridge, Londres: Harvard University Press, 1997.

BRITO, J. B. Literatura, cinema, adaptação. Graphos: revista da pós-graduação em Letras, João Pessoa, v.1, n. 2, p. 9-28, 2 semestre, 1996.

BRUSCHINI, Cristina. O trabalho das mulheres brasileiras nas décadas recentes. Revista Estudos Feministas. p. 179-199, ano 2, 2 semestre, 1994. Disponível em: <https://periodicos.ufsc.br/index.php/ref/article/viewFile/16102/14646>. Acesso em: 06 abr. 2016.

CAMPOS, Haroldo de. Metalinguagem \& outras metas: ensaios de teoria e crítica literária. São Paulo: Perspectiva, 2004.

CARDOSO, Lúcio. Crônica da casa assassinada. 13.ed. Rio de Janeiro: Civilização Brasileira, 2013.

O viajante. Rio de Janeiro: José Olympio, 1973. Obra inacabada.

CARELLI, Mario. Corcel de fogo. Tradução de Júlio Castañon Guimarães. Rio de Janeiro: Guanabara, 1988.

CATTRYSSE, Patrick. Descriptive adaptation studies: epistemological and methodological issues. London: Antwerpen-Apeldoorn \&Garant, 2014.

FLAUBERT, Gustav. Madame Bovary. Tradução de Hilana Heineberg. Porto Alegre: L\&PM Pocket, 2003.

FRIEDMAN, Norman. El punto de vista. In: SULLÁ, Enric. Teoria de la novela: antologia de textos de siglo XX. Barcelona: Grijelbo Mordadorin, 1996.

GOMES, Paulo Emílio Salles. A Personagem Cinematográfica. In. CANDIDO. Antonio et al. A personagem de fição. São Paulo: Perspectiva, 1968. p. 103-119.

GUIMARÃES, José Eugenio. Saraceni e a crônica da decadência familiar a partir de Lúcio Cardoso. 2014. Disponível em: < http://cineugenio.blogspot.com.br/2014/04/saraceni-ecronica-da-decadencia.html>.Acesso em: 14 set. 2016

HUTCHEON, Linda. Uma teoria da adaptação. Tradução de André Cechinel. Florianópolis: Editora da UFSC, 2011. 280 p.

KOZLOFF, Sarah. Invisible storytellers: voiceover narration in american fiction film. Berkeley: University of California Press, 1988.

LAZO, Vlademir. Eu era craque 15 abr. 2012. Disponível em: <http://www.cineplayers.com/perfil/paulo-cesar-saraceni/26925>. Acesso em: 25 mar.2016.

LEFEVERE, Andre. Tradução, reescrita e manipulação da fama. Tradução de Claudia Matos Seligmann. Bauru: EDUSC, 2007. NASSAR, Raduan. Lavoura arcaica. São Paulo: José Olympio, 1975.

NEIVA JR, Eduardo. A imagem. 2. ed. São Paulo: Ática, 1994.

ORMOND, Andrea. A Casa assassinada. In: Estranho Encontro (Blog). 2008. Disponível em:

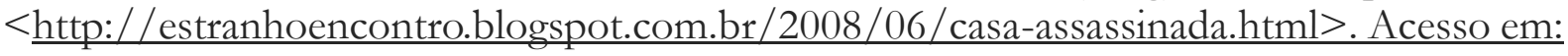
22 nov. 2015.

PINTO, Célia Regina Jardim. Feminismo, história e poder. Revista de Sociologia e Política. 
Curitiba, v.18, n.36, jun. 2010. Disponível em: <http://www.scielo.br/scielo.php?script $=$ sci_arttext\&pid=S0104-44782010000200003>. Acesso em: 20 abr. 2017.

PLAZA, Julio. Tradução intersemiótica. São Paulo: Perspectiva, 2001.

QUEIROS, Eça. O primo Basílio. São Paulo: KLICK editora, 1997.

SARACENI, Paulo César. Por dentro do cinema novo: minha viagem. Rio de Janeiro: Nova Fronteira, 1993.

SILVA, Carlos A. V da. Mrs. Dalloway e a reescritura de Virginia Woolf na literatura e no cinema. Tese de Doutorado, Universidade Federal da Bahia, 2007.

SKYLAR, Robert. História social do cinema americano. Tradução de Octávio Mendes Cajado. São Paulo: Cultrix, 1975.

TOLSTÓI, Leon. Ana Karenina. Tradução de Rubens Figueiredo. São Paulo: Editora Cosac Naify, 2015.

TOURY, Gideon. Descriptive Translation Studies and beyond. Amsterdam: John Benjamins, 1995.

\section{REFERÊNCIAS FILMOGRÁFICAS}

CASA assassinada. Direção: Paulo César Saraceni. Produção: Paulo César Saraceni e Mário Carneiro. Rio de Janeiro, 1971. (103min). Disponível em: <https://www.youtube.com/watch?v=elDrJ3sIsTI\&t=9s $>$. Acesso em: 10 ago. 2015.

LAVOURA arcaica. Direção: Luiz Fernando Carvalho. Produção: Luiz Fernando Carvalho. 2001. DVD (163min). 